\title{
Jumping through the hoops: the challenges of daffodil (Narcissus) classification
}

Article

Accepted Version

Könyves, K., David, J. and Culham, A. (2019) Jumping through the hoops: the challenges of daffodil (Narcissus) classification. Botanical Journal of the Linnean Society, 190 (4). pp. 389-404. ISSN 0024-4074 doi:

https://doi.org/10.1093/botlinnean/boz032 Available at https://centaur.reading.ac.uk/85267/

It is advisable to refer to the publisher's version if you intend to cite from the work. See Guidance on citing.

To link to this article DOI: http://dx.doi.org/10.1093/botlinnean/boz032

Publisher: Oxford University Press

All outputs in CentAUR are protected by Intellectual Property Rights law, including copyright law. Copyright and IPR is retained by the creators or other copyright holders. Terms and conditions for use of this material are defined in the End User Agreement.

www.reading.ac.uk/centaur 
Central Archive at the University of Reading

Reading's research outputs online 


\section{Jumping through the hoops: the challenges of daffodil classification}

1 Kálmán Könyves ${ }^{1,2 *}$, John David ${ }^{1}$, Alastair Culham ${ }^{2}$

$2 \quad{ }^{1}$ Royal Horticultural Society Garden Wisley, Woking, Surrey, GU23 6QB, United Kingdom

$3{ }^{2}$ University of Reading Herbarium, Harborne Building, School of Biological Sciences,

4 University of Reading, Whiteknights, Reading, RG6 6AS, United Kingdom

$5 *$ Correspondence:

6 Kálmán Könyves

7 kalmankonyves@rhs.org.uk

8

9 Running title: Hoop-petticoat daffodils 


\section{ABSTRACT}

13 Hoop-petticoat daffodils are a morphologically congruent group that has two distinct lineages

14 in the molecular phylogeny of Narcissus. It is possible that the morphological similarity is a

15 product of both historic and current low-level gene flow between these lineages. For the first

16 time we report population sampling from across the entire range of distribution covering both

17 the Iberian Peninsula and Morocco. In total 455 samples were collected from 59 populations.

18 Plastid DNA sequences of $m a t K$ and $n d h F$ were generated alongside 11 microsatellite loci to

19 permit comparison between plastid and nuclear lineage history. The plastid DNA phylogeny

20 was highly congruent with previous molecular studies and supported the recognition of these

21 two lineages of hoop-petticoat daffodils as separate sections. Assignment of samples to sections sometimes differed between plastid DNA and (nuclear) microsatellite data. In these cases, the taxa had previously been the focus of dissent in taxonomic placement based on morphology. These discrepancies could be explained by hybridisation and introgression among the two lineages during the evolution of hoop-petticoat daffodils and shows that placement of species in sections is dependent on the source of data used. This study underlines the complex evolutionary history of Narcissus and highlights the discrepancies between floral morphology and phylogeny, which provides a continuing challenge for the systematics of Narcissus. 
35 Daffodils, the genus Narcissus L., are one of the most iconic spring flowers, yet the taxonomy of the genus, which underpins their conservation and breeding, remains in flux. The last comprehensive monographic revision of the genus, at species level, was by Baker in 1875 (Burbidge \& Baker, 1875), although the system of subgenera and sections proposed by Fernandes $(1968,1975)$ has been largely followed in subsequent publications on the genus. The genus is split into two subgenera: Narcissus and Hermione (Haw.) Spach and 10-14 sections (Figure 1) (Fernandes, 1968; Aedo, 2013; Marques et al., 2017). Recent changes in the delimitation of sections mean that the established approach of using morphology to allocate species to sections is no longer reliable. Some sections are best defined on DNA evidence.

Narcissus section Bulbocodii DC. has traditionally been distinguished from the rest of Narcissus by the large funnel-shaped corona relative to the narrow tepals, a right angled attachment of the anther to the filament, and the declinate stamens and stigma which gives rise to a zygomorphic flower (Fernandes, 1968; Blanchard, 1990). This distinctive corona shape has given rise to the English common name "hoop-petticoat daffodil". The recognition of these daffodils dates to the late $16^{\text {th }}$ and the early $17^{\text {th }}$ century (David \& Könyves, 2013). The integrity of this group had not been questioned by morphological studies. This distinctive group has been recognised at different taxonomic ranks, ranging from genus (Corbularia; Salisbury, 1812), or subgenus ( $N$. subgenus Corbularia Pax, 1888), to section ( $N$. section Bulbocodii, De Candolle, 1815) and even as a single species (Baker in Burbidge \& Baker, 1875). The recognition of hoop-petticoat daffodils as a distinct genus has never been accepted widely, but a number of authors have treated it at subgeneric level (Ascherson \& 
petticoat daffodils, supported by morphological and cytological evidence, is as section

Hoop-petticoat daffodils are distributed from southwest France through the Iberian Peninsula, to Morocco and northwest Algeria. Natural populations of hoop-petticoat daffodils show a great range of morphological variation (Figure 2), that has resulted in disagreement in the number of taxa and the level at which they have been recognised (Fernandes, 1963; Webb, 1978; Barra \& López González, 1982; Fernández Casas, 1986a, 1996; Barra Lázaro, 2002; Vázquez Pardo, 2013). In addition to the morphological diversity within the basic hooppetticoat ground plan, along with a propensity for hybridisation between species (Blanchard, 1990; Aedo, 2013), a wide range of chromosome numbers have been reported (Fernandes, 1934, 1963; Zonneveld, 2008). All of these factors have led to an unstable classification indicated by the number of recognised taxa at species level or below ranging from 4-35 (Könyves, 2014).

Recent molecular evidence has indicated that the evolutionary history and taxonomy of section Bulbocodii is more complex than first thought. The first molecular study of Narcissus (Graham \& Barrett, 2004) used plastid DNA data and identified two separate clades comprising the section Bulbocodii sensu DC. making the section polyphyletic. Later studies with wider taxonomic sampling across Narcissus showed the same polyphyletic pattern in section Bulbocodii (Marques, 2010; Santos-Gally, Vargas, \& Arroyo, 2012; Fonseca et al., 2016). Moreover, other sections also show polyphyly: section Tazettae DC. (Santos-Gally et al., 2012), section Jonquillae DC. and section Pseudonarcissi DC. (Marques, 2010). These

81 results suggest that extensive hybridisation and subsequent gene flow may have contributed 82 to the complex genetic history of Narcissus. The most comprehensive study of the genus to 
date, Marques et al. (2017), using markers from three genomes (plastid, mitochondrial, and

nuclear ribosomal), found hoop-petticoat daffodils to be polyphyletic in both organellar and nuclear datasets. This led to the formal split of section Bulbocodii and the recognition of section Meridionalis I.Marques, Fuertes, Martins-Loução, Moharrek \& Nieto Fel. to include some species previously in $N$. section Bulbocodii. These two sections are distinguished on molecular evidence and there are, as yet, no clear morphological characters to separate them.

Narcissus is most diverse in the Iberian Peninsula and Northern Africa, and current treatments of this genus in these areas are synthetic accounts. The accounts vary in their scope, breadth of new knowledge added, and the chosen breadth of species concept used to encompass morphological diversity. The most recent account of taxa occurring in the Iberian Peninsula is the treatment in Flora iberica (Aedo, 2013). This treatment is a detailed revision and employs broadly defined species and recognises only a few infraspecific taxa. In contrast, the treatment in Flore Pratique du Maroc (Fennane, 2015) is a compilation of current knowledge with a narrower species concept applied. This leads to problems in comparing different treatments of hoop-petticoat daffodils as there is only partial overlap of the taxa between the Iberian Peninsula and Morocco and the species circumscriptions, even under the same name, differ. For example, Narcissus bulbocodium L. is accepted in both accounts, however Aedo (2013) treats N. bulbocodium as a variable species including N. obesus Salisb. as a synonym, in contrast to the view of Webb for Flora Europaea (1978) who treats it as subsp. obesus (Salisb.) Maire, or Zonneveld (2008) who treats it as a species: N. obesus. A further issue is the treatment of $N$. obesus in Morocco. Maire (1959) treats it as $N$. bulbocodium var. obesus (Salisb.) Baker. Fernandes (1968) also notes its presence in Morocco, as N. obesus. However, Fennane (2015) treats the Moroccan N. obesus as a synonym of $N$. tingitanus Fern.Casas, which has now been sunk into N. albicans (Haw.) 
108 Spreng. (Fernández Casas, 2016). There is strong molecular evidence for the acceptance of

109 obesus as a distinct taxon (Fonseca et al., 2016; Marques et al., 2017) at species or

110 subspecies level, based on predominantly Iberian material. Narcissus cantabricus DC. is also

111 treated differently in the two accounts: Fennane (2015) recognises two subspecies in his

112 account of Moroccan Narcissus, while Aedo (2013) does not for his account of species of the

113 Iberian Peninsula, even though one of the subspecies in Morocco has also been reported from

114 SE Spain (Fernandes, 1968).

115

116 A particularly controversial taxon is the entity originally described as $N$. cantabricus subsp.

117 luteolentus Barra \& G.López (Barra \& López González, 1982), that has been treated as a

118 species, N. blancoi Barra \& G.López (Barra Lázaro \& López González, 1992) or included in

119 N. albicans (Fernández Casas, 2016) or as a possible synonym of $N$. hedraeanthus (Webb \&

120 Heldr.) Colmeiro (Fernández Casas, 1984). The taxon was transferred to N. hedraeanthus

121 subsp. luteolentus (Barra \& G.López) Aedo by Aedo (2013) based on morphology. However,

122 Fonseca et al. (2016) supported its assignment to $N$. cantabricus based on plastid DNA

123 evidence.

125 For the remainder of the section Fennane (2015) accepts three species, all endemic to

126 Morocco. Narcissus romieuxii Braun-Blanq. \& Maire is treated as an ancient allopolyploid

127 hybrid of $N$. bulbocodium and $N$. cantabricus (Fernandes, 1959). The other two species, $N$.

128 peroccidentalis Fern.Casas and N. tingitanus were described by Fernández Casas (1996),

129 however he has since reduced these to synonymy with $N$. albicans. This is a confused name

130 applied to two different entities, a hoop-petticoat daffodil and a trumpet daffodil (Kington,

131 2008). Fernández Casas (2016) typified the name $N$. albicans on the hoop-petticoat daffodil.

132 Furthermore, two species from southern Morocco, N. jacquemoudii Fern.Casas and $N$. 
133 jeanmonodii Fern.Casas, have been accepted by some (Mathew, 2002; Rankou et al., 2015;

134 Marques et al., 2017), but are treated as synonyms of $N$. romieuxii by Fennane (2015).

135

136 To confound matters further, there are natural hybrids with other sections (Kington, 2008;

137 Aedo, 2013). Our study includes hybrids between a number of hoop-petticoat daffodils and

138 N. triandrus L. (sect. Ganymedes (Haw.) Schult.f.). Furthermore, there are crosses with other

139 sections with limited geographic range mostly occurring in the Iberian Peninsula (Fernández

140 Casas, 1986b, 1993).

141

142 The understanding of daffodil dispersal and the establishment of hybrid populations is based

143 on a very small number of studies. In a study of $N$. longispathus (subsection Pseudonarcissi)

144 Barrett, Cole, \& Herrera (2004) reported limited pollen flow and seed dispersal. However, in

145 a study of N. cavanillesii hybrids (section Braxireon) F1 progeny were found to have a

146 fitness advantage in establishment and later vegetative propagation (Marques et al., 2011),

147 that allows the long-term perennation of these populations in the wild. No such studies are

148 yet published for $N$. section Bulbocodii sensu Marques and N. section Meridionalis.

150 The various treatments of the hoop-petticoat daffodils both within the Iberian Peninsula, and

151 for Iberia and North Africa together, illustrate clearly the challenges to finding a consistent

152 taxonomy of the group. Interpretation of findings of previous molecular studies have been

153 constrained by limited geographic and within-species sampling. There is a need for

154 population level sampling across the entire range of these species. Here we use novel

155 microsatellite and plastid DNA data to examine populations of sections Bulbocodii and

156 Meridionalis throughout most of their distribution at a level of detail not previously

157 attempted. 
MATERIALS AND METHODS

160

PLANT MATERIALS

162

Material was collected in the form of either silica dried leaf material or as living plants across the natural distribution of Narcissus sections Bulbocodii sensu Marques and Meridionalis.

165 Herbarium vouchers were collected for each sampled population. Collecting permits were obtained from the local authorities (Universities in Morocco; National Parks and Regional Governments in Spain and Portugal). In total 455 samples were collected from 59 populations (Table S1). Populations were sampled according to accessibility or by haphazard sampling (Lowe, Harris, \& Ashton, 2004) ensuring at least 5 metres between samples to limit sampling of ramets. To maximise genetic variation, a minimum of 10 individuals were collected per population where possible. The sampling strategy was designed to sample genetic variation without endangering small populations. A combination of descriptions from Blanchard (1990) and Aedo (2013) was used for identification of samples.

To help elucidate the relationship of hoop-petticoat daffodils, 78 additional samples representing 24 taxa from other sections were also collected following the same procedures or purchased (suppliers listed in Table S2). Sequences for one additional daffodil, N. tazetta L., and three Sternbergia Waldst. \& Kit. species for outgroups, were downloaded from

179 GenBank (N. tazetta: HM011047 \& HM011012; S. greuteriana Kamari \& R.Artelari:

180 HM011031 \& HM010997; S. lutea (L.) Ker Gawl. ex Spreng.: HM011025 \& HM010992; S. sicula Tineo ex Guss.: HM011014 \& HM010984, matK and $n d h F$ respectively), voucher specimens given in Gage et al. (2011). 
MICROSATELLITE METHODS

185

186 Total genomic DNA was extracted using a modified CTAB protocol (Doyle \& Doyle, 1987).

187 Eleven of the 15 hoop-petticoat daffodil microsatellite markers reported in Könyves et al.

188 (2016) were amplified following their protocol. The allele dosage of polyploids cannot readily be established, therefore traditional population genetic techniques which rely on correct allele frequencies (e.g. STRUCTURE, Pritchard et al., 2000) cannot be applied. We used a presence-absence scoring of peaks to estimate polymorphism, similar to a dominant marker (e.g., amplified fragment length polymorphism [AFLP]) data set and used

193 discriminant analysis of principal components to identify clusters within the microsatellite dataset (DAPC, Jombart et al., 2010). To characterise the variability of the selected markers the total number of alleles per marker, the number of alleles per individual, the mean number of alleles per individual and the observed heterozygosity $\left(H_{\mathrm{o}}\right)$ were calculated. To assess the

197 variation between markers and within samples, and therefore the preliminary identification

198 power of the markers, an allelic diversity was calculated as the complement of Simpson's

199 diversity $\left(D=1-\sum\left\{p_{i}\left(p_{i}-1\right) / N(N-1)\right\}\right)$, where $p_{i}$ is the frequency with which the $i$ th

200 allele was detected). As some of the markers exhibited no alleles in some samples (null

201 genotypes) the proportion of null genotypes was also calculated. The presence of null

202 genotypes was confirmed by repeated PCR amplifications using both a labelled and

203 unlabelled forward primer, to rule out user error or possible adverse effect of the dye

204 labelling. The presence of null genotypes was expected due to incomplete transferability of

205 these markers in hoop-petticoat daffodils. Five samples (two samples from population Hue,

206 one sample each from populations Ald, JTiz, and Sdf; Table S1), that had failed fragment

207 analysis after successful PCR of one or more loci, were removed. In total 450 hoop-petticoat 
samples were included in the analysis. DAPC was conducted using the package adegenet ver.

Core Team, 2013).

212 The optimal number of clusters in the dataset was determined using the guidelines of Jombart

213 (2013). The model was run for $10^{6}$ iterations to search for convergence, retaining principal components that explained $95 \%$ of the variance. All eigenvalues were retained, as the number of the clusters was small. The clustering analysis identified four clusters. The two most populous ones, Clusters 1 and 3, were further analysed using DAPC to elucidate any

217 additional genetic structure.

PLASTID DNA METHODS

A section of the mat $K$ region was amplified with primers matK 2.1 and matK 5 or, in the case of weak amplification, with primers matK X and matK 5 (Ford et al., 2009). PCR reactions were performed in $30 \mu 1$ volumes containing final concentrations of $1 \times$ Bioline Biomix (Bioline Reagents Ltd., London, UK), $0.35 \mu \mathrm{M}$ of each primer, $0.13 \mathrm{mg} / \mathrm{ml} \mathrm{BSA} \mathrm{(bovine}$ serum albumin), $2.67 \%$ v/v DMSO (dimethyl sulfoxide) and 15ng DNA template. A few samples failed to amplify with any of the mat $K$ primer combinations. For these $\operatorname{trn} K$ was amplified, using primers trnK 570F and trnK 1710R (Samuel et al., 2005), as these flank the entire $m a t K$ region. The PCR protocol for $\operatorname{trn} K$ was $1 \times$ Bioline Biomix, $0.35 \mu \mathrm{M}$ of each primer, $0.2 \mathrm{~g} / \mathrm{ml} \mathrm{BSA,} 4 \% \mathrm{v} / \mathrm{v}$ DMSO and $15 \mathrm{ng}$ DNA template in $50 \mu \mathrm{l}$ total volume. The 3' end of $n d h F$ was amplified with primers ndhF 745F and ndhF 2110R (Terry, Brown, \&

231 Olmstead, 1997) for 45 samples representing all recovered matK haplotypes. PCR reactions

232 were each performed in $50 \mu 1$ volumes containing final concentrations of $1 \times$ Bioline Biomix, 
$0.35 \mu \mathrm{M}$ of each primer, $0.2 \mathrm{mg} / \mathrm{ml} \mathrm{BSA} \mathrm{(bovine} \mathrm{serum} \mathrm{albumin),} \mathrm{and} 15 \mathrm{ng}$ of DNA template.

PCR cycling conditions for all amplified regions are listed in Table 1.

The PCR products were separated on $1 \%$ agarose gels in $1 \times$ TAE buffer stained with 0.3 $\mu \mathrm{gml}^{-1}$ ethidium bromide. Gels were illuminated with UV light and photographs were taken to record the presence of PCR amplicons. Approximate size and concentration of the PCR amplicons was determined using HyperLadder ${ }^{\mathrm{TM}} 1 \mathrm{~kb}$ (Bioline Reagents Ltd, London, UK). Direct sequencing of PCR products was carried out by Beckman Coulter (UK) Ltd, High Wycombe, UK; Source BioScience, Nottingham, UK; and Macrogen Europe, Amsterdam,

242 Netherlands in both forward and reverse direction. Sequence trace files were assembled and edited using Seqman II (DNAStar, Inc., Madison, WI, USA). Sequences were aligned with the MUSCLE algorithm using the default parameters (Edgar, 2004) implemented in ebioX 1.6 (Martínez Barrio et al., 2009). The ends of the alignments were trimmed to the point where all sequences were present and base calls were unambiguous.

To explore the relationships between the sampled populations and other sampled Narcissus a statistical parsimony network was constructed from the matK dataset using TCS ver. 1.21 (Clement, Posada, \& Crandall, 2000) under the 95\% statistical parsimony criterion. Phylogenetic trees were constructed through Bayesian inference (BI) in MrBayes ver. 3.2 (Ronquist et al., 2012) according to the best-fit model of evolution identified by MrModeltest ver. 2.3 (Nylander, 2004). To avoid overfitting of the model, BI analysis of the matK dataset was performed using only the haplotypes identified by TCS. BI analysis of the combined dataset including the mat $K$ haplotypes and the corresponding $n d h F$ sequences was used to improve the resolution of the matK phylogenetic tree. The incongruence of the matK and $n d h F$ datasets was assessed with the incongruence length difference (ILD) test in PAUP* 
4.0b 10 (Swofford, 2003). All BI analyses were conducted with two separate runs, each of four chains. The analyses for the matK and the combined datasets were run for 2,500,000 and $5,000,000$ generations respectively, sampling every 1000 generations. Autocorrelation of the sampled generations was tested in Microsoft Excel 2011 by checking the correlation between subsequent generations. Burn-in was identified by assessing convergence with Tracer ver. 1.5 (Rambaut \& Drummond, 2009). Trees from the first $25 \%$ of the sampled generations were discarded.

\section{GENETIC DIVERSITY ESTIMATORS}

For each taxon, the number of haplotypes, the total number of different alleles across all loci

$(A)$, the number of private alleles across all loci $\left(A_{\mathrm{p}}\right)$ and the genotypic richness $(\mathrm{R}=\mathrm{G}-1 / \mathrm{N}-1$;

where $\mathrm{G}$ is the number of multilocus genotypes and $\mathrm{N}$ is the number of genotyped samples,

Dorken \& Eckert 2011) were calculated. Multilocus genotypes for each sample were identified using the $R$-library polysat ver. 1.3-2 (Clark \& Jasieniuk, 2011). Samples with zero distance were considered to belong to the same multilocus genotype.

RESULTS

276

MICROSATELLITE VARIATION

279 A summary of the variability within microsatellite markers is given in Table 2. The number

280 of alleles per locus ranged from five to 25 , while the observed heterozygosity $\left(H_{o}\right)$ was between 0.138 and 0.424 . Most of the samples appeared homozygous with the mean number of alleles per individual ranging from 1.099 to 1.532 . The allelic diversity of the amplified 
markers was between 0.353 and 0.832 , while the frequency of null genotypes ranged from $0.4 \%$ to $30 \%$.

285

286 The DAPC of 450 individuals revealed a separation of the microsatellite dataset into four

287 main clusters (Figure 3 A). Narcissus bulbocodium populations were assigned to clusters 1, 2

288 and 3. Narcissus cantabricus and $N$. romieuxii were in Cluster 3. The two subspecies of $N$.

289 hedraeanthus formed Cluster 4. Narcissus obesus was indistinguishable from $N$.

290 bulbocodium samples included in Cluster 1 . The hybrid individuals were assigned to clusters

291 including the hoop-petticoat daffodil parent (apart from one individual of $N . \times$ fosteri Lynch,

a hybrid of $N$. bulbocodium and $N$. triandrus, and one individual of $N . \times$ cazorlanus

293 Fern.Casas, hybrid of $N$. hedraeanthus and $N$. triandrus, which were assigned to Cluster 3

294 with $N$. cantabricus and $N$. romieuxii). A further DAPC conducted on Cluster 1 detected two

295 sub-clusters (Figure 3 B). These represented the $N$. bulbocodium $N . \times$ fosteri (Sub-cluster 1.1)

296 and N. obesus populations (Sub-cluster 1.2). The further DAPC conducted on Cluster 3

297 detected three sub-clusters (Figure 3 C). The three sub-clusters do not appear to correlate

298 with established taxonomic groups.

299

300 PLASTID DNA VARIATION

301

302 The total aligned and analysed length of the matK dataset was 836bp including a $6 \mathrm{bp}$

303 insertion. TCS identified 46 different haplotypes (GenBank accession numbers: XXXXXX -

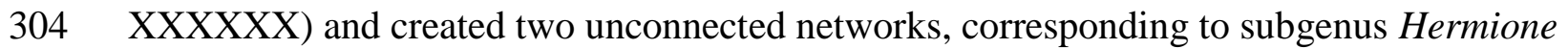
305 (h43-h46) and subgenus Narcissus (Figure 4 A).

306 
307 The hoop-petticoat daffodil sequences were grouped into 22 haplotypes, the remaining 20

308 haplotypes belonged to other daffodil samples in subgenus Narcissus. Narcissus section

309 Bulbocodii sensu Marques and section Meridionalis appeared as two distantly related groups,

310 separated by a minimum of $22 \mathrm{bp}$ differences. The matK (Figure S1), and the combined matK

311 and $n d h F \mathrm{BI}$ analyses (Figure 5) recovered a topology congruent with Marques et al. (2017).

312 The correspondence of the DAPC and plastid DNA results is shown in Figure 5. The

313 correspondence of floral morphology and sectional classification is shown in Figure 4.

314

315 The DAPC results (Figure 3 A, B) showed N. obesus to be grouped with N. bulbocodium in

316 section Bulbocodii sensu Marques, however, the plastid DNA analyses placed it in section

317 Meridionalis. Narcissus hedraeanthus subsp. luteolentus was placed in the same cluster as $N$.

318 hedraeanthus subsp. hedraeanthus by DAPC, but it was indistinguishable from $N$.

319 cantabricus and $N$. romieuxii in the plastid DNA analysis. The plastid DNA analyses and

320 DAPC differ in the placement of some samples carrying haplotypes H29, H32 and H34: the

321 former placing them in section Bulbocodii, the latter in section Meridionalis (Figure 4). Three

322 of these populations occur in southern Morocco and two in central Spain. The geographic

323 distribution of the plastid DNA haplotypes and the DAPC clusters is shown in Figure 6.

\section{DIVERSITY ESTIMATORS}

327 Narcissus section Bulbocodii sensu Marques, comprising purely N. bulbocodium samples in 328 our analysis, contained 13 different plastid DNA haplotypes, and 34 private microsatellite 329 alleles. In comparison section Meridionalis, comprising five taxa, also had 13 haplotypes, but

330 only 15 private alleles. Genotypic richness $(R)$ was 1 in all cases except $N$. cantabricus, 331 which was 0.95 (Table 3). 
The DAPC and plastid DNA analyses, presented here, each recovered two separate hooppetticoat daffodil groups. These two groups correspond with the two hoop-petticoat daffodil sections recognised by Marques et al. (2017). Our results support the recognition of these sections by recovering the divergent groups through analysis of microsatellite markers, which have broader coverage of the nuclear genome than ITS used by Marques et al. (2017). The recognition of the two sections is strongly supported by molecular evidence, but the putative morphological markers for these sections are not definitive. The two distinct lineages (Figure 5) have an apparently identical range of floral morphology (Figure $2 \mathrm{~A}-\mathrm{H}$ section

Meridionalis, Figure 2 I-L as section Bulbocodii sensu Marques). This emphasis on floral morphology to distinguish taxa has led to other characters being overlooked that may distinguish these sections. A parallel can be drawn with the relationships within Scilla L. s.l. where taxonomy based on floral characters is inconsistent with the taxa recognised using non-floral characters (Speta 1998a; Speta 1998b), the latter appearing to be supported by molecular data (Ali et al., 2012).

The sampling employed by Fonseca et al. (2016) and Marques et al. (2017) focused mostly on Iberian hoop-petticoat daffodils. Our study includes much wider sampling in Morocco and in section Meridionalis than these earlier studies, which gives a more comprehensive picture of the species relationships among hoop-petticoat daffodils. As the two widely sampled species, $N$. cantabricus and $N$. romieuxii, could not be separated with plastid DNA analyses, there were no grounds, based on these data, to evaluate their infraspecific taxa. Narcissus romieuxii is endemic to Morocco and is an ancient allotetraploid hybrid of $N$. bulbocodium and N. cantabricus (Fernandes, 1959). Its flower colour appears intermediate, ranging from 
white to whitish-yellow (Fernandes, 1959). The results of the microsatellite analyses show the same pattern, a cluster including $N$. cantabricus and $N$. romieuxii (Cluster 3), without clear separation between them. The plastid DNA results indicate that $N$. cantabricus was the seed parent of $N$. romieuxii, while the microsatellite results indicate introgression of $N$. romieuxii and $N$. cantabricus. Due to the limited information provided in the original descriptions of $N$. peroccidentalis and $N$. tingitanus, it is uncertain whether samples attributable to these species were collected and analysed for this study. From their brief descriptions, and the more recent synonymy with $N$. albicans, as circumscribed by Fernández Casas (2016), they would likely be part of section Meridionalis.

Thirteen taxa have been described below species level in N. bulbocodium, more than in any other species of hoop-petticoat daffodil and this variation seems to be reflected in the genetic diversity measured by plastid DNA. This species had the highest haplotype diversity, carrying 13 different haplotypes, but the DAPC showed more uniform genetic structure, with most samples assigned to sub-cluster 1.1. However, two N. bulbocodium populations (Ald,

$373 E d c$ ) in central Spain were assigned to Cluster 2. These plants also carried matK haplotypes exclusive to them, but they appeared morphologically similar to the rest of the $N$. bulbocodium samples. So far, no corresponding morphological discontinuity has been identified to explain this variation. Apart from the treatment of $N$. obesus (discussed later), $N$. bulbocodium is widely treated as a single variable species (Webb, 1978; Aedo, 2013;

378 Fennane, 2015; Fonseca et al., 2016; Marques et al., 2017). However, recently Fernández

379 Casas (2017a,b) delineated two species that broadly belong to N. bulbocodium: one, $N$.

380 saltuum Fern.Casas, was new to science and reported to occur in Northern Spain; the other,

$381 N$. tenuifolius Salisb., although originally described by Salisbury (1796) and long regarded as 382 a synonym of $N$. bulbocodium, is applied by Fernández Casas to plants from the southern tip 
383 of Andalusia. Neither of these species overlap geographically with the populations in Cluster

3842 or any other sampled populations. Moreover, Fonseca et al. (2016) treats localized but

385 unresolved plastid DNA variation as evidence for infraspecific taxa in N. bulbocodium,

386 recognizing four subspecies and five varieties.

387

388 Three populations in Southern Morocco further highlighted the complex genetic variation found in N. bulbocodium. Two of these, Our and Tafr, were identified as N. bulbocodium in the field and this was confirmed with plastid DNA evidence, however DAPC of the microsatellites places these same populations in section Meridionalis with $N$. cantabricus and $N$. romieuxii. In contrast, the third population, Tig, was field-collected as $N$. cantabricus (Figure 2 I), but identified as $N$. bulbocodium with plastid DNA, however DAPC supported the field identification. This pattern is congruent with a hybrid origin for these populations with either $N$. bulbocodium and $N$. cantabricus (or $N$. romieuxii) as the seed parent, and shows more recent hybridisation. This pattern could also explain the differing treatments of N. jacquemoudii and N. jeanmonodii both by Marques et al. (2017) and Fennane (2015). In the former these are recognized species belonging to section Bulbocodii sensu Marques, but treated as synonyms of $N$. romieuxii by the latter author, and therefore part of section Meridionalis. Future sampling in the High Atlas, the type locality of both species, may help to resolve this.

402

403 A population in Spain (JD11-8), from which two plants were sampled, included one morphologically typical of $N$. bulbocodium and one typical of $N$. cantabricus, and while each sample grouped in its respective cluster in DAPC, both carried the same $N$. bulbocodium matK haplotype. This is most easily explained by gene flow through introgression. The two 
possible that the rarity of hybrids between the two in the Iberian Peninsula is due to their differences in geographical range and possibly ecological preferences. However, this shows that patterns similar to that in southern Morocco can be found in the Iberian Peninsula and highlights the need to conduct studies across the whole of the natural distribution.

413 The evidence to accept N. obesus as a species (Fonseca et al., 2016; Marques et al., 2017), rather than a subspecies of $N$. bulbocodium (Aedo, 2013), is further supported by our results. Sub-cluster 1.2 of the DAPC corresponds to N. obesus, and its placement in the plastid DNA analysis is the same as that shown by Fonseca et al. (2016) using $m a t K$ and $\operatorname{trn} L-F$ sequences. However, the assignment of $N$. obesus to section Bulbocodii sensu Marques in the DAPC, but to section Meridionalis in the plastid DNA analysis raises the question whether this species has also arisen through hybridisation between the two hoop-petticoat daffodil sections. The base chromosome number of $N$. obesus is $\mathrm{x}=13$, while the rest of the hoop-petticoat daffodils have $x=7$ (Fernandes, 1934; Zonneveld, 2008). This could be congruent with allotetraploid origin and subsequent chromosome losses/fusions (De Storme \& Mason, 2014). Whichever of the two sections this species is correctly placed in, it is clear that it should be recognised as a species, based on chromosome number and DNA sequence, however this species cannot be reliably differentiated using morphological characters. It is pertinent to note that $N$. obesus and $N$. bulbocodium occur together in some locations, including population Joa.

Narcissus hedraeanthus is endemic to Spain, and limited to a small area between Albacete,

Ciudad Real, Jaen and Granada (Barra \& López González, 1986; Aedo, 2013). While

430 morphologically distinct, the stem is at an angle of 45 degrees or less to the ground opposed to the upright stem found in all other species (Blanchard, 1990), its taxonomic position has been often debated. It was previously treated as a subspecies or variety of $N$. bulbocodium 
434 (Fernández Casas, 1982). Fonseca et al. (2016) and Marques et al. (2017) have shown that $N$.

435 hedraeanthus is closely related to N. cantabricus and belongs to section Meridionalis and this

436 is confirmed by our findings.

437

438 At subspecies rank the taxon luteolentus has been placed in either $N$. hedraeanthus (Aedo,

439 2013) or N. cantabricus (Barra \& López González, 1982); but also at species rank as $N$.

440 blancoi (Barra Lázaro \& López González, 1992). Based on plastid DNA data, Fonseca et al.

441 (2016) accepts $N$. cantabricus subsp. luteolentus. We collected fifteen samples from four

442 populations. Of these, three populations were identified as subsp. luteolentus (Hue; JD11-14;

$443 J D 11-17, \mathrm{~N}=14)$, while the remaining population $(J D 12-8, \mathrm{~N}=1)$ was identified as subsp.

444 hedraeanthus based on morphology. The DAPC assigned all $N$. hedraeanthus samples to

445 Cluster 4, together with a sample of $N . \times$ cazorlanus, a known hybrid of $N$. hedraeanthus and

446 N. triandrus. The plastid DNA haplotype of subsp. hedraeanthus was unique (H8), however,

447 the samples from the subsp. luteolentus populations shared haplotype H1 with N. cantabricus

448 and $N$. romieuxii. The possibility of $N$. hedraeanthus subsp. luteolentus being a unique form

449 of N. cantabricus was debated by Fernández Casas (1984), and Barra \& López González

450 (1986). Our data support treatment of luteolentus as a potential hybrid between $N$.

451 hedraeanthus and N. cantabricus (which would be indicated as the nothospecies $N . \times$

452 blancoi).

453

454 CONCLUSION

455

456 Combining microsatellite data with plastid DNA data has highlighted incongruence between

457 patterns of relationship recovered from nuclear and organellar genomes that is indicative of

458 hybridisation at many levels within Narcissus evolution. There remains a clear signal that 
459 there are two lineages of hoop-petticoat daffodils, consistent with those recently identified by

460 Marques et al. (2017) using ITS and organellar DNA. However, there is also evidence of

461 ongoing hybridisation between these two sections. The haplotype diversity recovered in these

462 two sections is similar, and this is congruent with evidence of evolutionary age, $N$. section

463 Bulbocodii sensu Marques was estimated at 3.43 Myr and $N$. section Meridionalis excluding

464 N. obesus (which has distinct haplotypes), 3.37 Myr (Marques et al., 2017). There remains

465 the conundrum of taxa that can be recognised morphologically such as $N$. cantabricus and $N$.

466 romieuxii, but are genetically indistinguishable and, in contrast, taxa which have been

467 synonymised based on morphology but have distinct genetic profiles, such as N. obesus, and

468 subspecies luteolentus. Here we advise extreme caution in using plastid genome data alone to

469 name new Narcissus taxa and argue strongly for a multi-evidence approach.

470

471

ACKNOWLEDGMENTS

472

473 The authors would like to thank Rafaa Shkwa, Gábor Sramkó, Anna Trias Blasi, and Brian

474 Duncan for assisting K.K. with collecting plant material. The authors would like to thank

475 Chris Yesson for constructive comments on a draft of the manuscript and two anonymous

476 reviewers for their feedback. The authors would also like to thank the Royal Horticultural

477 Society for funding this project, and the Alpine Garden Society for its contribution to funding

478 the development of the microsatellite markers.

479 
482 Aedo C. 2013. Narcissus L. In: Talavera S, Andrés C, Arista M, et al., eds. Flora iberica.

Plantas vasculares de la Península Ibérica e Islas Baleares. Vol. XX, Liliaceae-Agavaceae.

Madrid: Real Jardín Botánico, CSIC, 340-397.

Ali SS, Yu Y, Pfosser M, Wetschnig W. 2012. Inferences of biogeographical histories

within subfamily Hyacinthoideae using S-DIVA and Bayesian binary MCMC analysis implemented in RASP (Reconstruct Ancestral State in Phylogenies). Annals of Botany 109: 95-107.

Ascherson P, Graebner P. 1907. Synopsis der Mitteleuropaïschen Flora 3. Leipzig:

Wilhelm Engelmann.

Baker JG. 1888. Handbook of the Amaryllideae, including the Alstroemerieae and Agaveae.

492 London: Bell.

Barra A, Blanco E, Grijalbo J. 2011. Narcisos ibéricos: junquillos, campanillas, capirotes o trompones. Quercus 301: 40-52.

Barra Lázaro A. 2002. Notas sobre Narcissus L. (Amaryllidaceae), III. Anales del Jardín Botánico de Madrid 60: 222-224.

497 Barra Lázaro A, López González G. 1992. Notas sobre el género Narcissus L. (III). Anales del Jardín Botánico de Madrid 50: 123.

Barra A, López González G. 1982. Notas sueltas sobre el género Narcissus en España.

500 Anales del Jardín Botánico de Madrid 39: 67-68.

501 Barra A, López González G. 1986. Diferencias entre Narcissus cantabricus DC. subsp.

502 luteolentus Barra \& G. López y Narcissus hedraeanthus (Webb \& Heldr.) Colmeiro. Anales del Jardín Botánico de Madrid 43: 185-187.

504 Barrett SCH, Cole WW, Herrera CM. 2004. Mating patterns and genetic diversity in the 
wild Daffodil Narcissus longispathus (Amaryllidaceae). Heredity 92: 459-465.

Blanchard JW. 1990. Narcissus: a guide to wild daffodils. Woking: Alpine Garden Society.

Burbidge FW, Baker JG. 1875. The Narcissus: its History and culture. London: L. Reeve \&

508 Co.

509 De Candolle AP. 1815. Flore française. Paris: Desray.

510 Clark L V., Jasieniuk M. 2011. POLYSAT: An R package for polyploid microsatellite 511 analysis. Molecular Ecology Resources 11: 562-566.

512 Clement M, Posada D, Crandall KA. 2000. TCS: A computer program to estimate gene

513 genealogies. Molecular Ecology 9: 1657-1659.

514 David J, Könyves K. 2013. The earliest published report of Narcissus bulbocodium in

515 cultivation. Daffodil, Snowdrop and Tulip Yearbook: 36-38.

516 Dorken ME, Eckert CG. 2011. Severely reduced sexual reproduction in northern

517 populations of a clonal plant, Decodon verticillatus (Lythraceae). Journal of Ecology 89:

$518 \quad 339-350$.

519 Doyle JJ, Doyle JL. 1987. A rapid DNA isolation procedure for small quantities of fresh leaf 520 tissue. Phytochemical Bulletin 19: 11-16.

521 Edgar RC. 2004. MUSCLE: multiple sequence alignment with high accuracy and high throughput. Nucleic Acid Research 32: 1792-1797.

523 Fennane M. 2015. Narcissus. In: Fennane M, Ibn Tattou M, El Oualidi J, eds. Flore pratique

$524 d u$ Maroc, Volume 3. Rabat: Institut Scientifique, Université Mohammed V de Rabat.

525 Fernandes A. 1934. Nouvelles études caryologiques sur le genre Narcissus L. Coimbra:

526 Imprensa da Universidade.

527 Fernandes A. 1959. On the origin of Narcissus romieuxii Br.-Bl. \& Maire. Boletim da

528 Sociedade Broteriana II. 33: 103-117.

529 Fernandes A. 1963. Sobre a evolução no subgénero Corbularia do género Narcissus L. 
530 Memórias da Academia das ciências de Lisboa, classe de ciências 8: 1-21.

531 Fernandes A. 1968. Keys to the Identification of Native and Naturalised Taxa of the Genus

532 Narcissus L. R.H.S. Daffodil and Tulip Year Book: 37-66.

533 Fernandes A. 1975. L'Evolution chez le genre Narcissus L. Anales del Instituto Botánico A.

$534 \quad$ J. Cavanilles 32: 843-872.

535 Fernández Casas FJ. 1982. De Flora Occidentale. Fontqueria 1: 9-12.

536 Fernández Casas FJ. 1984. Remiendos y enmiendas en el género Narcissus L. Fontqueria

537 6: $35-50$.

538 Fernández Casas FJ. 1986a. Cuatro novedades en Narcissus L. Fontqueria 10: 9-11.

539 Fernández Casas FJ. 1986b. Acerca de unos cuantos Narcisos norteños. Fontqueria 11: 15-

54023.

541 Fernández Casas FJ. 1993. Narcissorum notulæ. Fontqueria 36: 271-272.

542 Fernández Casas FJ. 1996. Narcissorum notulæ, II. Fontqueria 44: 253-262.

543 Fernández Casas FJ. 2016. Narcissorum notulæ, XLV-XLVII. Fontqueria 56: 467-480.

544 Fernández Casas FJ. 2017a. Narcissorum notulæ, XLIX. Fontqueria 56: 555-556.

545 Fernández Casas FJ. 2017b. Narcissorum notulæ, L. Fontqueria 56: 557-558.

546 Fonseca JP, Levy A, Henriques R, Costa JC, Neto C, Robalo J. 2016. Phylogenenetic

547 approach of the section Bulbocodii D.C. of Narcissus based on cpDNA. A case of taxonomic

548 inflation? Plant Biosystems 150: 787-798.

549 Ford CS, Ayres KL, Toomey N, Haider N, Van Alphen Stahl J, Kelly LJ, Wikström N,

550 Hollingsworth PM, Duff RJ, Hoot SB, Cowan RS, Chase MW, Wilkinson MJ. 2009.

551 Selection of candidate coding DNA barcoding regions for use on land plants. Botanical

552 Journal of the Linnean Society 159: 1-11.

553 Gage E, Wilkin P, Chase MW, Hawkins J. 2011. Phylogenetic systematics of Sternbergia

554 (Amaryllidaceae) based on plastid and ITS sequence data. Botanical Journal of the Linnean 
Society.

556 Graham SW, Barrett SCH. 2004. Phylogenetic reconstruction of the evolution of stylar polymorphisms in Narcissus (Amaryllidaceae). American Journal of Botany 91: 1007-1021. Jombart T. 2013. A tutorial for Discriminant Analysis of Principal Components (DAPC) using adegenet 1.4-0. $\mathrm{R}$ vignette.

560 Jombart T, Ahmed I. 2011. adegenet 1.3-1: new tools for the analysis of genome-wide SNP data. Bioinformatics 27: 3070-3071.

Jombart T, Devillard S, Balloux F. 2010. Discriminant analysis of principal components: a new method for the analysis of genetically structured populations. BMC Genetics 11: 1-15. Kington S. 2008. The International Daffodil Register and Classified List 2008. London: The Royal Horticultural Society.

Könyves K. 2014. Taxonomy to underpin cultivar identification in hoop-petticoat daffodils. Ph.D. Thesis. University of Reading.

Könyves K, David JC, Culham A. 2016. Microsatellite Markers for Hoop-Petticoat Daffodils ( Narcissus sect. Bulbocodii; Amaryllidaceae). Applications in Plant Sciences 4:

5701500127.

Lowe A, Harris S, Ashton P. 2004. Ecological Genetics: Design, Analysis, and Application. Oxford: Blackwell Publishing. Maire R. 1959. Flore de l'Afrique du Nord. Paris: Paul Lechevalier. Marques I. 2010. Evolutionary outcomes of natural hybridization in Narcissus

575 (Amaryllidaceae): the case of $N . \times$ perezlarae s.l. Ph.D. Thesis. Universidade De Lisboa. Marques I, Aguilar JF, Martins-Louçao MA, Moharrek F, Feliner GN. 2017. A threegenome five-gene comprehensive phylogeny of the bulbous genus Narcissus

578 (Amaryllidaceae) challenges current classifications and reveals multiple hybridization events. 579 Taxon 66: 832-854. 
Narcissus hybrids: low fertility is overcome by early hybrid vigour, absence of exogenous

2009. Annotation and visualization of endogenous retroviral sequences using the Distributed Annotation System (DAS) and eBioX. In: BMC Bioinformatics., S18.

Mathew B. 2002. Classification of the genus Narcissus. In: Hanks GR, ed. Narcissus and Daffodil: The genus Narcissus. London: Taylor \& Francis, 30-52. Biology Centre, Uppsala University.

590 Pax F. 1888. Amaryllidaceae. In: Engler A, Prantl K, eds. Die Natürlichen Pflanzenfamilien. 591 Leipzig: Verlag von Wilhelm Engelmann, 97-124. multilocus genotype data. Genetics 155: 945-959.

594 Rambaut A, Drummond AJ. 2009. Tracer version 1.5. Available at

595 http://tree.bio.ed.ac.uk/software/tracer/.

\section{Rankou H, Culham A, Sghir Taleb M, Ouhammou A, Martin G, Jury SL. 2015.}

597 Conservation assessments and red listing of the endemic moroccan flora (monocotyledons). Botanical Journal of the Linnean Society 177: 504-575.

Richter K. 1890. Plantae Europeae. Enumeratio systematica et synonymica plantarum 600 phaenerogamicarum in Europa sponte crescentium vel mere inquilinarum. Leipzig: Verlag von Wilhelm Engelmann. 
605 Salisbury RA. 1796. Prodromus stirpium in horto ad Chapel Allerton vigentium. London.

606 Salisbury RA. 1812. On the cultivation of Rare Plants, especially such as have been

607 introduced since the Death of Mr. Philip Miller. Transactions of the Horticultural Society of

608 London 1: 261-366.

609 Samuel R, Kathriarachchi H, Hoffmann P, Barfuss MHJ, Wurdack KJ, Davis CC,

610 Chase MW. 2005. Molecular phylogenetics of Phyllanthaceae: evidence from plastid matK

611 and nuclear PHYC sequences. American Journal of Botany 92: 132-141.

612 Santos-Gally R, Vargas P, Arroyo J. 2012. Insights into Neogene Mediterranean

613 biogeography based on phylogenetic relationships of mountain and lowland lineages of

614 Narcissus (Amaryllidaceae). Journal of Biogeography 39: 782-798.

615 Speta F. 1998a. Systematische Analyse der Gattung Scilla L. s.l. (Hyacinthaceae). Phyton 616 (Horn) 38: 1-224.

617 Speta F. 1998b. Hyacinthaceae. In: Kubitzki K, ed. The Families and Genera of Vascular 618 Plants III. Monocotyledons - Lilianae (except Orchidaceae). Berlin Heidelberg: Springer 619 Verlag, 261-285.

620 De Storme N, Mason A. 2014. Plant speciation through chromosome instability and ploidy 621 change: Cellular mechanisms, molecular factors and evolutionary relevance. Current Plant 622 Biology 1: 10-33.

623 Swofford DL. 2003. PAUP*. Phylogenetic Analysis Using Parsimony (*and Other 624 Methods). Version 4.0b 10.

625 Terry RG, Brown GK, Olmstead RG. 1997. Examination of Subfamilial Phylogeny in 626 Bromeliaceae Using Comparative Sequencing of the Plastid Locus ndhF. American Journal 627 of Botany 84: 664-670.

628 Vázquez Pardo FM. 2013. Anotaciones a la diversidad de Narcissus bulbocodium L., 629 (Amaryllidaceae) en Extremadura (España). Folia Botanica Extremadurensis 7: 13-21. 
630 Webb D. 1978. Taxonomic notes on Narcissus L. Botanical Journal of the Linnean Society

631 76: 298-307.

632 Zonneveld BJM. 2008. The systematic value of nuclear DNA content for all species of

633 Narcissus L. (Amaryllidaceae). Plant Systematics and Evolution 275: 109-132.

634 
635

636

637

638

639

640

641

642

643

644

645

646

647

648

649

650

651

652

653

654

659 655 haplotypes. B) Error! Reference source not found.Recoloured according to the DAPC 656 cluster and sub-cluster assignments. Labels show identifications made in the field or ex situ. 657 Species names in black represent hoop-petticoat taxa, grey labels represent other taxa. All 658 section Bulbocodii sensu Marques haplotypes refer to N. bulbocodium, apart from the ones

Figure Legends

Figure 1. Examples of floral variation within and between Narcissus sections and subsections sensu Marques et al. (2017). Narcissus subsection Pseudonarcissi: A) N. nobilis,
B) N. cyclamineus,
C) N. moschatus,
D) N. bujei; Ganymedes:
E) N. triandrus; Nevadensis:

F) N. segurensis; Juncifolii: G) N. assoanus; Braxireon: H) N. cavanillesii; Meridionalis: I)

N. cantabricus; Apodanthi: J) N. rupicola; Bulbocodii sensu Marques: K) N. bulbocodium;

Jonquillae: L) N. jonquilla, M) N. viridiflorus; Dubii: N) N. tortifolius; Angustifolii: O) N. elegans; Tazettae: P) N. tazetta, Q) N. papyraceus; Aurelia: R) N. broussonetti; Narcissus subsection Narcissus: S) N. poeticus; Serotini: T) N. serotinus Scale bar $=5 \mathrm{~cm}$. Copyright the authors except for B (J. Bilsborrow) and O (T. Sanders).

Figure 2. Examples of morphological variation of hoop-petticoat daffodils: A, B) $N$. romieuxii; C) N. hedraeanthus subsp. hedraeanthus; D) N. hedraeanthus subsp. luteolentus; E, F) N. obesus; G, H, I) N. cantabricus; J, K, L) N. bulbocodium. Scale bar $=5 \mathrm{~cm}$.

Figure 3. Results of the DAPC. A) Individual membership probabilities of each of four genetic clusters ( $k=4$ ) of 450 individuals; B) Results of DAPC of Cluster 1 samples, showing membership probabilities of either of two genetic clusters $(k=2)$; C) Results of DAPC of Cluster 3 samples, showing membership probabilities of each of three genetic clusters $(k=3)$. Population order follows the natural distribution from north to south (top to bottom).

654 Figure 4. Haplotype network of $m a t K$ sequences. A) Coloured circles represent the observed with labels. The size of the circle is proportional to the haplotype frequency. Open circles 
660 indicate inferred haplotypes, dashes indicate indel positions. The length of connecting lines 661 does not have meaning.

662 Figure 5. Bayesian inference majority rule consensus tree of the combined matK and $n d h F$ 663 dataset. Posterior probabilities are shown at nodes. Scale bar shows the number of 664 substitutions per site. $N . c .=N$. cantabricus, $N . r .=N$. romieuxii. Haplotype colours and 665 names correspond to Figure 4 A. Labels correspond to Figure 1 and Figure 2.

666 Figure 6. Geographic distribution of A) the hoop-petticoat daffodil matK haplotypes 667 [numbers and colours correspond to Figure 4 A] and B) distribution of the DAPC clusters 668 [colours correspond to Figure 3, labels show population codes]. Areas within the dotted lines 669 indicate regions in which these species are found but from which we did not have opportunity 670 to sample. 
671 Figure S1. Bayesian inference tree of the $m a t K$ dataset. Posterior probabilities are shown at 672 nodes. Scale bar shows the number of substitutions per site. Haplotype colours and names 673 correspond to Figure 4 A. N. c. $=$ N. cantabricus, $N . r .=N$. romieuxii. 674 
675 Table captions

676

677 Table 1. Details of the PCR cycling conditions for the plastid DNA markers.

678

679 Table 2. Summary statistics of the 11 amplified microsatellites based on 450-455 hoop-

680 petticoat daffodil samples. $\mathrm{H}_{\mathrm{o}}=$ observed heterozygosity; s.e. $=$ standard error. $\mathrm{N}$ indicates

681 number of samples across the table.

682

683 Table 3. Genetic diversity estimators for each taxon. $\mathrm{N}_{\mathrm{H}}=$ the number of different haplotypes

$684 \mathrm{~N}_{\mathrm{C}}=$ the number of different clusters, $\mathrm{A}=$ the total number of different alleles across all loci;

$685 A_{p}=$ the number of private alleles across all loci; $R=$ the genotypic richness. $N$ without

686 subscript indicates number of samples across the table.

687

688 Table S1. Geographic location and voucher information of hoop-petticoat daffodil samples.

$689 \mathrm{~N}=$ number of sampled individuals included in the plastid DNA (cpDNA) and microsatellite

690 (SSRs) analyses.

691

692 Table S2. Geographic location or source, and voucher information of Narcissus samples. $\mathrm{N}=$ 693 number of individuals included in the chloroplast DNA analysis; N/K = not known; N/A = 694 not applicable. 